DR JOE ATKINSON is honorary research fellow in political studies, University of Auckland.

\section{Mixed bag with an eye on PBRF deadline}

Scooped: The Politics and Power of Journalism in Aotearoa New Zealand, edited by Martin Hirst, Sean Phelan and Verica Rupa. Auckland: AUT Media. 2012, 232 pp. ISBN 9780958299763.

$\mathrm{T}_{\mathrm{t}}$ HERE IS a very good and useful book waiting to escape from this collection on journalism and public affairs in New Zealand. Its editorial troika of scholars (from three different universities) have set themselves laudable but editorially exacting goals, made more demanding by the accelerated climate of academic publishing. The stated editorial intent is to address the "tensions between [journalistic] practitioners and academics ... exemplified in the enduring tendency to see "theory" and "practice" as irrevocably opposed' (p. 21), and to 'redirect [New Zealand journalism] towards a more critical and reflexive position of intellectual confidence and independence' (p. 24).

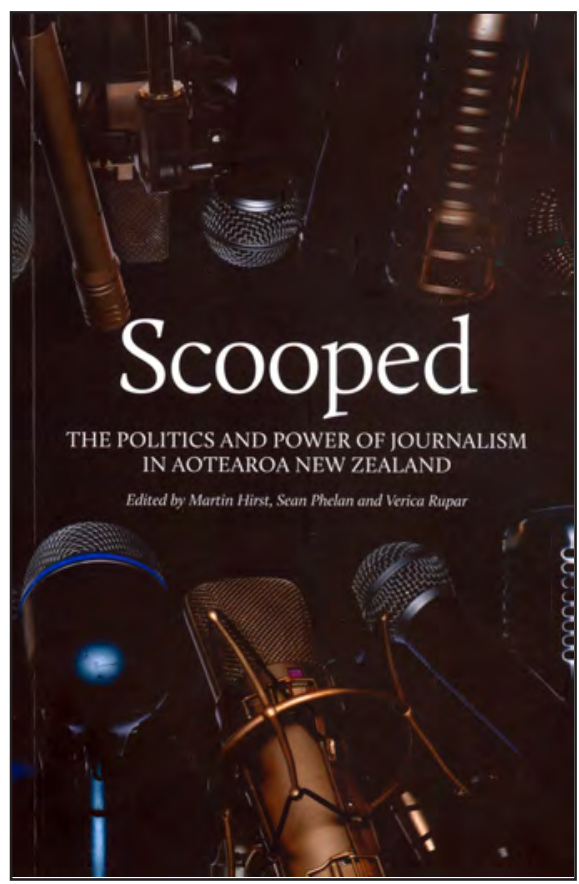

These goals might reasonably be taken to entail a quest for common ground through a cooperative exchange with enough theoretical sophistication to attract academics but free from academic baggage that might deter practitioners. A strongly directive editorial hand from a single journalist/academic might have delivered this; a committee of academics from three different universities was unlikely to do so.

The collection features 13 contributions by 16 media academics and journalists on topics such as the commercialisation of the New Zealand public sphere, the history of Pākeha 
media coverage of Te Tiriti issues, the journalistic tendency to see power as something only non-journalists have, the demonisation of Russell Coutts in the media, the experiences of a Pacific Islander within Radio New Zealand, and how to make New Zealand journalism more investigatory. The most consistent theme is one of disenchantment with New Zealand journalism, but the chapters vary widely with respect to degrees of originality, theoretical explicitness and direction, empirical support, clarity, cogency and accessibility.

In the absence of any common framework, Scooped does more to illustrate the tensions between journalists and academics (and within each occupational group) than to resolve them. It is not just that the journalists (and the academics with journalist backgrounds) generally write more clearly, and with less jargon and/or theoretical baggage than many of the academics, but also that the chapters most directly concerned to address the journalist-academic divide are also the one's least likely to persuade the other side.

Lead editor Martin Hirst's Marxist analysis of the class position of New Zealand journalists is a case in point. Marx was extraordinarily prescient about the strengths and weaknesses of capitalism, but as John Lanchester (2012) explains in a recent
London Review of Books article, his class analysis was less successful. Marx divided the world into opposing classes composed of owners and workers. There were gradations within and between these classes, of course, but Marx could hardly anticipate the bewildering complexity and multiplicity of the productive relations that would develop and the related inability of workers to unite and organise themselves against a moving target:

Marx did not foresee, as no one else did and I don't think anyone could, the variety of different forms of capitalism that would evolve ... There are lots of different capitalisms and it's not clear that a single analysis which embraces all of them as if they were a single phenomena can be valid. (Lanchester, 2012)

Attempts to apply class analysis to the contemporary world often tie analysts in knots trying to account for non-materialist deviations from the basic model, and that is what happens here. Hirst strives somewhat ponderously and with numerous scholarly references to 'establish the class nature of journalism as a set of work practices with technical, mechanical (technological), economic (labour value) and social (domination-subordination) characteristics' (p. 53). He concludes: 
For journalists as a social grouping their economic location may well be that of workers (social labour), but their class position (their habitus and their conformity to the norms of doxa) may diverge from this because of the relatively important role of ideological and cultural-political practices in the journalism field. A concrete and immutable location in the relations of production cannot, therefore, be automatically ascribed to journalists based on their economic status as wage labour. (Hirst, 2012 p. 55)

Since has taken eight plodding, jargon-riddled pages to arrive at this blindingly obvious conclusion - and without direct reference to the New Zealand situation - it is fair to ask what the journey was for. In his final seven pages, Hirst does list a handful of New Zealand examples, but has nothing original or even interesting to say about them. Copious elliptical references to secondary sources sometimes degenerate into nonsense.

Referring to McNair's work on cultural chaos, for instance, Hirst asks: 'Will this breakdown of traditional forms of social control in the newsroom fuel the "media-led expansion of capitalist modernity across the globe", or challenge the "injustices and excesses of globalisation and cultural imperialism"?' He concludes delphically: 'It will, by necessity, be "all of the above"'(pp. 60-61). Not all Marxists write this badly, of course, and Hirst's other writings show he can write well when he wants to (or is better edited?), but in a book that seeks to introduce academics to journalists and vice versa, this kind of obscurity is, to say the least, disobliging.

The other theory-heavy chapters are much better written. Wayne Hope's excellent chapter on the history of the New Zealand public sphere, for instance, blends theoretical sophistication with narrative clarity, and is packed with useful local detail. General readers might be slightly more daunted by Peter Thompson's sophisticated mapping of McQuail's extended normative typology onto Galtung's model of media and social systems, or with Sean Phelan's less successful discussion of Lukes' and Foucault's contrasting positions on power and agency, but both chapters are readable and interesting. Other worthwhile contributions are by journalists recounting their personal experiences-Selwyn Manning's fascinating account of the birth of the Scoop website for instance-or by former journalists turned academic researchers-Margie Comrie on politician-journalist relations, and Donald Matheson on ethnocentrism in international news coverage.

The lack of firm editorial direction is also indicated by unresolved 
contradictions. Perhaps the strangest of these is Ruth Thomas' apparently uncritical observation that a primary function of the 'inverted pyramid' format of news writing is 'to persuade the reader to continue to buy the newspaper' (p. 161) and further that 'news values are not just a list of elements to be learnt by rote, but the key to appealing to the readership in order to fulfil the profit motive' (p. 166).

It may be true historically that the inverted pyramid displaced more epistolary styles of news-writing in a period of intense commercial competition and was designed to make news easier to digest by a mass popular readership, but the fabled profitability of the Pulitzer press had more to do with its epideictic modes of address, headline and picture-heavy pageformatting, and rabble-rousing campaigns, than with its more telegraphic modes of narration. Thomas's claim that news values are essentially profit-driven is equally misleading, and difficult to square with (to take one example) Hager's assertion that serious investigatory journalism is degraded 'when profits trump news values'.

In short, Scooped is a mixed bag. It is much more academic, that its three Dunmore Press predecessors, and more theoretically-oriented in consequence, but it loses out to them in terms of production quality, consistent editorial direction and readability.

Why is this? One possible reason might be that its publication coincides with the latest performance-based research funding round. It missed the PBRF publication deadline by a whisker, but the scramble for inclusion could explain its ramshackle construction, poor production values, and lack of editorial coherence. It looks like what it is: a collection edited by a committee, printed by a cost-accountant (with a cramped 8.5pt typeface) and designed to be counted rather than read. This is a great pity, because many of its chapters deserve a much wider readership than this collection is likely to attract.

\section{References}

Comrie, M., and McGregor, J. (Eds.). (1992). Whose news? Palmerston North: Dunmore

McGregor, J. (Ed.) (1996). Dangerous democracy? Palmerston North: Dunmore, 1996

McGregor, J., and Comrie, M. (2002). What's news? Palmerson North: Dunmore.

Lanchester, J. (2012, April 5). Marx at 193. London Review of Books, 34(7), p. 9. 